\title{
Functional genomics of the Neotyphodium Iolii / ryegrass symbiosis
}

\author{
R.D. JOHNSON, S. BASSETT, M. CHRISTENSEN, C. GABORIT, L. JOHNSON, A. KHAN, A. KOULMAN, S. \\ RASMUSSEN, C. VOISEY and G. BRYAN \\ AgResearch Ltd., Tennent Drive, Private Bag 11008, Palmerston North, New Zealand \\ gregory.bryan@agresearch.co.nz
}

\begin{abstract}
Neotyphodium lolii is a fungal endophyte that lives entirely within the intercellular spaces of its grass host, perennial ryegrass (Lolium perenne, L.). Infection is symptomless and the endophyte relies on the host plant for dissemination via the seed. The association is mutually beneficial since the endophyte confers a number of biotic and abiotic advantages to the host. This paper presents an overview of the functional genomics approaches we are using at AgResearch to dissect the molecular basis of this symbiosis and will broadly describe the fields of genomics, transcriptomics, proteomics and metabolomics, as applied to this system. We have used isogenic ryegrass lines infected or uninfected with endophyte in combination with a suite of molecular biology tools, including Expressed Sequence Tags (ESTs), cDNA and Affymetrix GeneChip ${ }^{\circledR}$ microarray analysis, 2D-gel electrophoresis (to identify novel proteins associated with symbiosis), and metabolic profiling. By using a multidisciplinary approach we aim to identify genes which are important in both the establishment and maintenance of symbiosis, as well as elucidate how endophyte confers enhancements to its host. Keywords: Neotyphodium, Epichloë, symbiosis, functional genomics
\end{abstract}

\section{Introduction}

Neotyphodium and Epichloë spp. (phylum Ascomycota, family Clavicipitaceae) are closely related asexual and sexual endophytic fungi, respectively that form associations with temperate grasses belonging to the family Poaceae. Epichloë endophytes encompass antagonistic through to mutualistic interactions that cause no disease, whereas the Neotyphodium endophytes are exclusively mutualistic (Glenn et al. 1996; reviewed in Schardl et al. 2004). For example, $N$. lolii and $N$. coenophialum are fungal endophytes that live entirely within the intercellular spaces of perennial ryegrass (Fig. 1) and tall fescue, respectively. Infection is symptomless and the endophyte relies entirely on the host plant for dissemination via the seed or through vegetative structures (Philipson \& Christey 1986; reviewed by Schardl et al. 2004). The association is mutually beneficial since the endophyte confers a number of biotic and abiotic advantages to the host, including enhanced plant growth, protection from certain mammalian and insect herbivores, enhanced resistance to nematodes, resistance to some fungal pathogens and in some associations, enhanced drought tolerance (Arechevaleta et al. 1989; Kimmons et al. 1990; Gwinn \& Gavin 1992; Schardl \& Phillips 1997; Clay \& Holah 1999; Scott 2001; Schardl 2001; Johnson et al.2003). Endophyte infection has also been implicated in modification of root morphology, osmotic adjustment and mineral uptake (Malinowski \& Belesky 1999; Malinowski et al. 1999). Some of these benefits are due to the production of fungal secondary metabolites such as the pyrrolopyrazine (peramine), aminopyrrolizidine (loline), ergopeptine (ergovaline) and indole diterpene (lolitrem) alkaloids (Bush et al. 1997; Blankenship et al. 2001; Panaccione et al. 2001; Spiering et al. 2005; Tanaka et al. 2005; Young et al. 2006), some of which can also cause mammalian toxicosis (Bacon et al. 1977; Fletcher \& Harvey 1981;
Lane et al. 2000; Panaccione et al. 2001; Easton et al. 2002; Wang et al. 2004; Gallagher et al. 1982; Young et al. 2006). Evidence has also accumulated showing that the host plant has a significant effect on the regulation of fungal secondary metabolites (Lane et al. 2000) and more recently it has been shown that the expression of fungal genes involved in alkaloid production are up-regulated in planta (Tanaka et al. 2005; Young et al. 2005). In addition, certain fungal-produced secondary metabolites have been shown to accumulate to very high levels; lolines for example can accumulate to concentrations of up to $2 \%$ dry weight (Craven et al. 2001; Spiering et al. 2002). The endophytes also remain metabolically active throughout the growth of the host grass (Tan et al. 2001) and compounds associated with endophyte infection are therefore continually produced during the life cycle of its host plant.

Apart from the characterised role of the above mentioned fungal secondary metabolites during symbiosis, many of the other observed endophyte effects on their host plants have not been elucidated. To gain a better understanding of these processes during endophyte grass associations, we have initiated a multidisciplinary study to link the knowledge gained from basic biology and cytology with the fields of genomics, transcriptomics, proteomics and metabolomics. To achieve this we are using isogenic ryegrass lines infected or uninfected with endophyte and a combination of Expressed Sequence Tags (ESTs), Affymetrix GeneChip ${ }^{\circledR}$ analysis, 2D-gel electrophoresis (to identify novel proteins associated with symbiosis), and metabolic profiling (Fiehn 2002). To aid our proteomics approach (which requires gene sequence information specific to the endophyte), we have also generated both fungal genomic and fungal EST resources.

This paper will present an overview of the functional genomics approaches we are using at AgResearch to identify genes which are important in both the establishment and maintenance of symbiosis. In addition, by combining transcriptomics with metabolomics, we intend to elucidate how endophyte infection influences host secondary metabolism, which we hypothesise is correlated with many of the endophyte conferred enhancements to its host.

\section{Genomics Resources}

Genomic libraries are listed in Table 1. These include an N. lolii small insert plasmid library, an $N$. lolii Lambda Zap (Stratagene) phagemid library, an $N$. lolii Bacterial Artificial Chromosome (BAC) library with a 7-fold redundancy (Amplicon Express), as well as a Fosmid library of E. festucae strain Fl1. In a targeted approach we have also used degenerate PCR to conserved domains of both non-ribosomal peptide synthetase (NRPS) and polyketide synthase (PKS) enzymes (Finking \& Marahiel 2004; Gaffoor et al. 2005) to generate mini-libraries of these gene families, which are commonly involved in secondary metabolite biosynthetic pathways. We have used these in conjunction with our other libraries to identify at least 13 NRPS (Johnson et al. 2007a) and 10 PKS genes in the Neotyphodium/Eplichloë complex.

\section{Functional Analysis by Gene Disruption}

Functional analysis, by gene disruption or deletion, is commonly employed with filamentous fungi to determine the role of genes 
Table 1 Genomic and cDNA libraries for N. Iolii and E. festucae.

\begin{tabular}{lccccc}
\hline Library & Type & Species & Insert size & Vector & $\begin{array}{c}\text { Number } \\
\text { unigenes }\end{array}$ \\
\hline Small insert & genomic & N. lolii & $3-5 \mathrm{~kb}$ & pBluscript & na \\
Lambda Zap & genomic & N. lolii & $4-12 \mathrm{~kb}$ & $\lambda$ Zapll & na \\
Fosmid & genomic & E. festucae & $30-35 \mathrm{~kb}$ & na \\
BAC & genomic & N. lolii & 140 kb & pECBAC1 & 2 \\
NRPS & genomic & Neotyphodium/Epichloe spp. & $300 \mathrm{bp}$ & pCR2.1Topo & 8 \\
PKS & genomic & Neotyphodium/Epichloe spp. & $300 \mathrm{bp}$ & pCR2.1Topo & 10 \\
CS32 & cDNA & N. lolii & $716 \mathrm{bp}$ & $\lambda$ TriplEx2 & 2011 \\
CS36 & cDNA & N. lolii/ L. perenne & $377 \mathrm{bp}$ & pCR2.1Topo & 2285 \\
\hline
\end{tabular}

that have unknown function, or to confirm the roles for those with tentative assignments based on bioinformatics. Studies in the grass-endophyte symbiosis have already provided important information for genes which are either essential for stable symbioses, for example NoxA encoding NADPH oxidase (Tanaka et al. 2006) and SidF encoding a novel extracellular siderophore (Johnson et al. 2007b) (Fig. 2), or involved in fungal secondary metabolism, such as those for the peramine (Tanaka et al. 2005), lolitrem (Young et al. 2006) and ergovaline (Panaccione et al. 2001; Fleetwood et al. 2006) biosynthetic pathways. We have also performed gene disruptions in two NRPS genes involved in the production of uncharacterised secondary metabolites (L. Johnson et al. unpublished results; Harzar et al. 2007) and are currently comparing these disrupted pathway mutants to wildtype endophyte using both metabolomics and microarray analysis to determine which compounds these pathways are likely to synthesise (Lane et al. 2007; Johnson et al. 2007c). Additionally, we have disrupted genes that have a role in fungal signalling such as acy $A$ encoding adenylate cyclase from E. festucae (Voisey et al. 2007a) (Fig. 3) and other genes with unknown function, for example $\mathrm{Nc} 25$, which is one of the most abundantly expressed transcripts in the symbiosis (Johnson et al. 2007d) (Fig. 4).

The identification of further genes, differentially expressed during the symbiosis, through Affymetrix GeneChip ${ }^{\circledR}$ experiments (Johnson et al. 2007c; Voisey et al. 2007b) will provide many more candidates for future functional analysis and elucidation of their roles in this symbiosis.

\section{Transcriptomics Resources}

Expressed sequence tag (EST) libraries are listed in Table 1. We have generated extensive transcriptomic capabilities that comprise EST databases of both fungal and plant origin. For fungal libraries mycelia were harvested from in vitro cultures, grown in either minimal or complete media, and RNA harvested for reverse transcription into cDNA as described in Johnson et al. (2007e). In the latter case, ESTs were generated using Suppression Subtractive Hybridisation (SSH) (Diachenko et al. 1996) technology in order to enrich for transcripts differentially expressed during the symbiosis (Johnson et al. 2007e). Subtraction was carried out in both the forward and reverse directions in order to create six libraries containing both up- and down-regulated ESTs for three physiological states (9-day-old seedlings, immature expanding leaf tissue, and mature sheath and blade tissue).

We generated eight independent EST libraries. Two were from $N$. lolii grown in vitro (together designated CS32; Table 1) and six were from suppressive subtractive hybridisations between endophyte infected and endophyte free perennial ryegrass (together designated CS36; Table 1). A total of 5493 and 3896
ESTs were sequenced for CS32 and CS36, respectively. For library CS32, ESTs assembled into 412 contigs and 1599 singletons to provide a set of 2011 unigenes with an average length of 716 base pairs. For library CS36, ESTs assembled into 654 contigs and 1631 singletons to provide a set of 2285 unigenes with an average length of 377 base pairs. Overlap of expression between the two in vitro fungal derived libraries that comprise CS32 and between the combined up-regulated and down-regulated SSH libraries was determined on the basis of contig membership. In both cases the majority of contigs or singletons showed no overlap indicating that most unisequences were library specific.

Functional categories were assigned using the MIPS Functional Catalogue (FunCat) (Ruepp et al. 2004) and are represented as pie charts for CS32 and CS36, respectively (Figs. 5A \& 5B).

Analysis of the SSH libraries identified several fungal genes that have a known role in the symbiosis, for example lolitrem biosynthesis (Young et al. 2006), B-1, 6-glucanase (Moy et al. 2002), a proteinase (Reddy et al. 1996), a chitinase (Li et al. 2004), as well as others with no obvious homology to other genes. Johnson et al. (2003) also identified two fungal genes ( $\mathrm{Nc12}$ and $\mathrm{Nc25}$ ), from the tall fescue/N. coenophialum association in common with this study. To obtain accurate data on the expression of these and other candidate genes we have performed both cDNA microarray (Johnson et al. 2006) and Affymetrix GeneChip ${ }^{\circledR}$ analyses (Voisey et al. 2007b; Johnson et al. 2007c).

\section{Affymetrix GeneChip ${ }^{\circledR}$ Analysis}

To further unravel the complex molecular interplay between endophytes and their grass hosts we performed a transcriptomic study using an Affymetrix (NimbleExpress ${ }^{\mathrm{TM}}$ ) dual species $(N$. lolii/L. perenne) GeneChip ${ }^{\circledR}$ to analyse gene expression from perennial ryegrass in association with either a Neotyphodium species (N. lolii) or an Epichloë species (E. festucae), as well as from these endophytes grown in vitro (Johnson et al. 2007c; Voisey et al. 2007b). Additionally, we have hybridised our GeneChips ${ }^{\circledR}$ with perennial ryegrass plants associated with mutant endophyte strains that contain a single gene deletion of interest (Johnson et al. 2007b; Johnson et al. 2007d; Voisey et al. 2007a). These analyses have enabled us to identify candidate 'symbiotic' genes; an important subset of fungal or ryegrass genes that are only induced during the symbiotic stage. To date we have discovered 90 symbiotic fungal genes where expression of these was only detected on chips hybridised with endophyte-infected perennial ryegrass. The most abundantly expressed gene from FL1-infected perennial ryegrass is Nc25; a novel fungal gene previously shown to be highly expressed in different plant-fungal associations, but absent in cultures of $N$. coenophialum (Johnson et al. 2003; Johnson et al. 2007d). Other genes shown to be 
Figure 1 Cross section of perennial ryegrass tillers infected with $E$. festucae strain Fl1 expressing green fluorescent protein (EGFP).

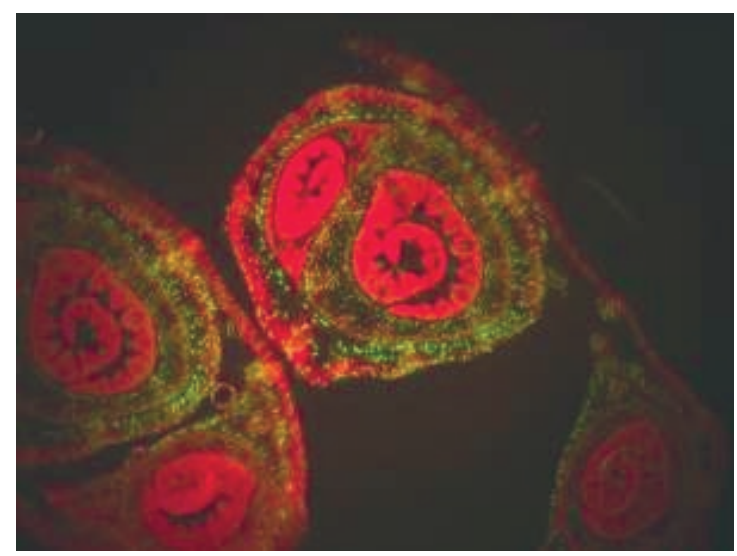

Figure 2 Comparison of wild-type (WT) and individual siderophore minus mutants $(\triangle \operatorname{sidF})$ associated with perennial ryegrass (Johnson et al. 2007b).

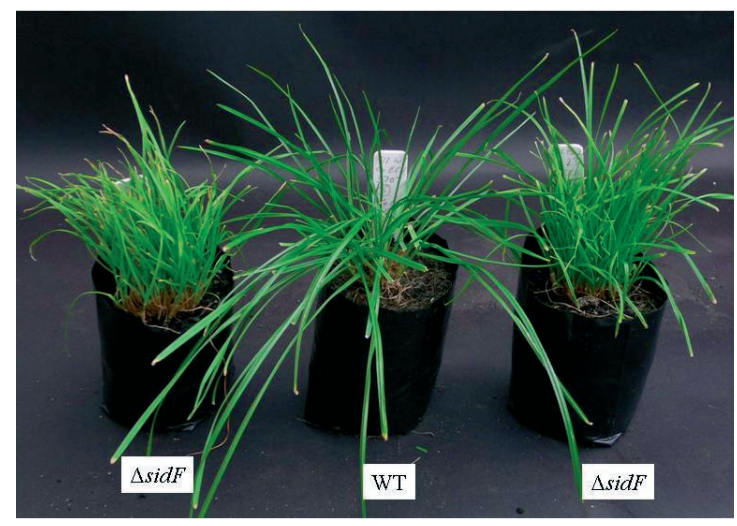

abundantly expressed are the lolitrem and ergovaline biosynthetic pathway genes. These genes are expressed abundantly in planta and lowly or not at all in culture (Fleetwood et al. 2006; Young et al. 2006), validating the results obtained here. Of greatest interest are the number of highly expressed fungal genes that have no annotations (using BLASTX, InterproScan, or Gene Ontology), indicating that they are novel. Future investigation of these genes should yield informative insights into the molecular regulation of grass-endophyte symbioses.

We have also identified approximately 800 or 1200 endophyte genes from F11 or Lp19, respectively, that are significantly upregulated in planta versus in vitro growth conditions (Fig. 6). Following validation of a subset of our differentially expressed genes by Real-Time RT-PCR, we will be in a position to explore in more detail the function of these genes during the symbiosis.

\section{Proteomics Resources}

We have also utilised proteomic approaches to identify both plant and fungal proteins involved in the symbiotic interaction. This approach faces the challenge of trying to identify a small specific subset of proteins within infected plants from among the large number of highly abundant proteins present in plant tissues that are not specifically involved in the symbiotic interaction. We adopted
Figure 3 Growth in culture of E. festucae wildtype and adenylate cyclase (acyA) disruption mutants. 1. E. festucae $\triangle$ acyA34 (disrupted); 2. E. festucae $\triangle$ acyA42 (disrupted); 3. E. festucae $\triangle a c y A 47$ (disrupted); 4. E. festucae E19 (Ectopic insertion); 5. E. festucae Fl1 (Wild-type); $6 . \quad E$. festucae E49 (Ectopic insertion)

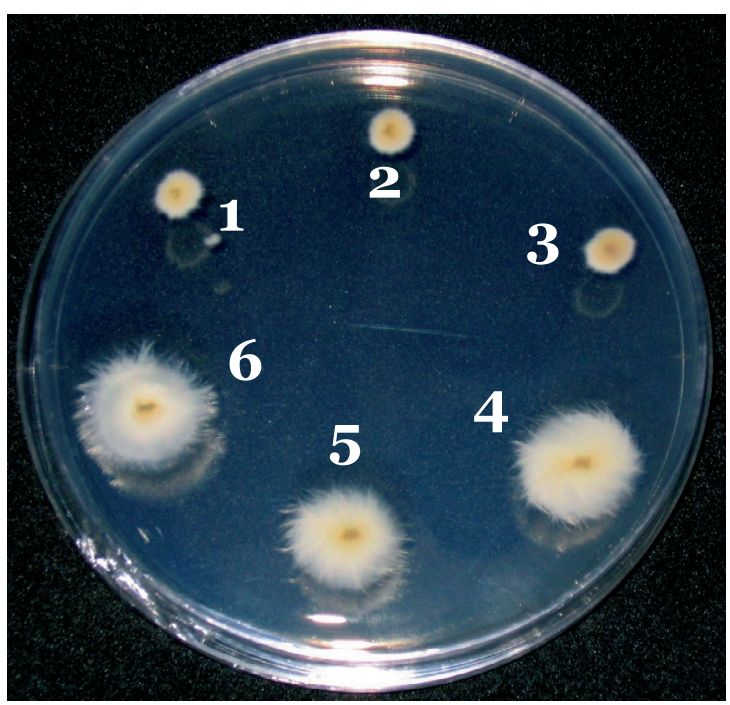

two main approaches to overcome this: differential purification of proteins from within the intercellular spaces of infected leaves and focusing on secreted fungal proteins. We began by characterising the fungal proteome using 2D gel electrophoresis to identify total (Fig. 7) and secreted proteins from in vitro fungal cultures in order to determine the overlap between proteins expressed in culture and those present in infected plants. To assist our proteomics approach, all of the fungal EST sequences were translated in silico into all possible reading frames and imported into a MASCOT database, which uses mass spectrometry data to identify proteins from primary sequence databases (Perkins et al. 1999). By interrogating this database with peptide fragmentation data obtained from MALDI-TOF and MS/MS mass spectrometry, we can now routinely identify $50 \%$ of protein spots isolated from $2 \mathrm{D}$ electrophoresis gels. The likelihood of identifying a protein spot correlates directly with the size and coverage of the EST database. Therefore the availability of the genome sequence should lead to significant improvements in identification of proteins using proteomics.

Differential purification of proteins from within the intercellular space has proven to be a valuable approach for identifying fungal proteins that may play a role in symbiosis. We have also been able to successfully identify a number of plant proteins, reflecting the fact that the ryegrass EST database contains an estimated 15,000 non-redundant sequences. An abundant fungal protein found exclusively in the intercellular fluid of infected ryegrass was characterised as a trypsin-like serine protease. An EST corresponding to this gene was also identified in the SSH subtractive libraries (Johnson et al. 2007e), and RT-PCR as well as GeneChip ${ }^{\circledR}$ analysis confirms that this gene is highly induced in planta. We over-expressed this gene in the fungus using a highly expressed constitutive promoter and the over-expressing strains have been infected into plants. Analysis of this symbiota is currently underway. We have also identified and characterised a number of fungal proteins with putative roles in cell wall 
Figure 4 Deletion of Nc25 leads to the specific elimination of an oligopeptide in planta.

Wild type

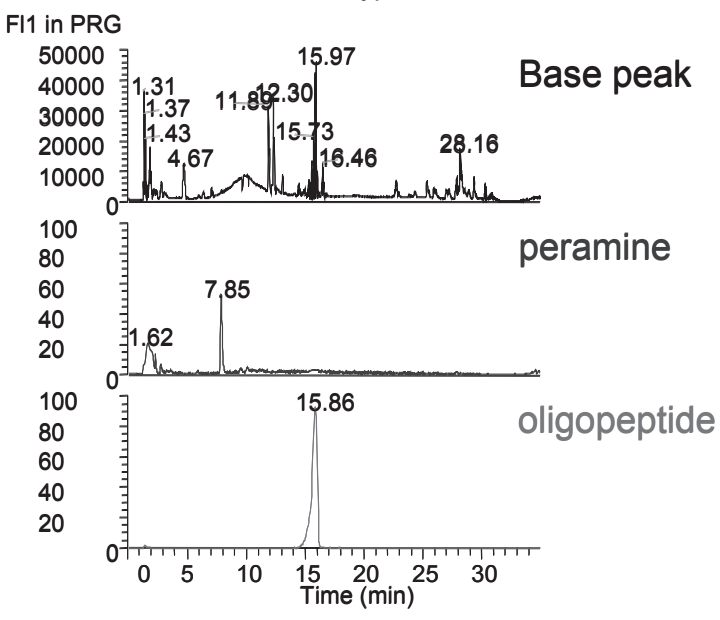

LCMS on ryegrass extracts infected with wild type N. lolii or a mutant deleted for Nc25.

biogenesis. An additional benefit of the proteomic analysis of secreted fungal proteins has been the identification of the mature processed peptides. We have found that the program SignalP (Bendtsen et al. 2004) is effective at identifying cleavage sites associated with secretion from predicted amino acid sequences (see for example Johnson et al. 2007d).

\section{Metabolomics}

Studies based on gene expression profiling and proteomics have in the past assumed simple correlations between gene expression, protein expression and metabolic states. However, the recent field of metabolomics (Fiehn 2002; Bhalla et al. 2005) has revealed that the end result of gene expression most often results in complex metabolic profiles that are difficult to interpret in terms of simple gene expression data alone (Gygi et al. 1999). To date few groups have combined the fields of transcriptomics, proteomics, and metabolomics in an integrated approach to correlate the metabolic phenotype with that of transcription and protein expression (Sumner et al. 2003; Fridman \& Pichersky 2005).

We are using a metabolomics approach to understand the metabolic relationship between $N$. lolii and its host grass during symbiosis. Our Affymetrix dual species GeneChips ${ }^{\circledR}$ provide the ideal opportunity to link gene expression with the metabolism of both the plant and the endophyte. The combination of metabolomics with microarray gene expression data will enable us to annotate cellular function rather than inferring molecular function from sequence homology alone, and is more informative with regard to phenotype from a systems biology perspective (Cao et al. 2007). We intend to gain an overview of the major metabolites affected by endophyte infection and are developing models to describe metabolic interactions.

To compare metabolite profiles against our transcriptomic resources, tissues were dissected which overlapped those originally taken for the SSH libraries, except that blade tissue was treated separately from mature (sheath) tissue, and we did not look at seedlings. We have focussed our current analysis on carbohydrates, amino acids, phenolics, polar compounds, and endophyte alkaloids. Tissue specific differences were apparent for the different metabolite classes, emphasising the

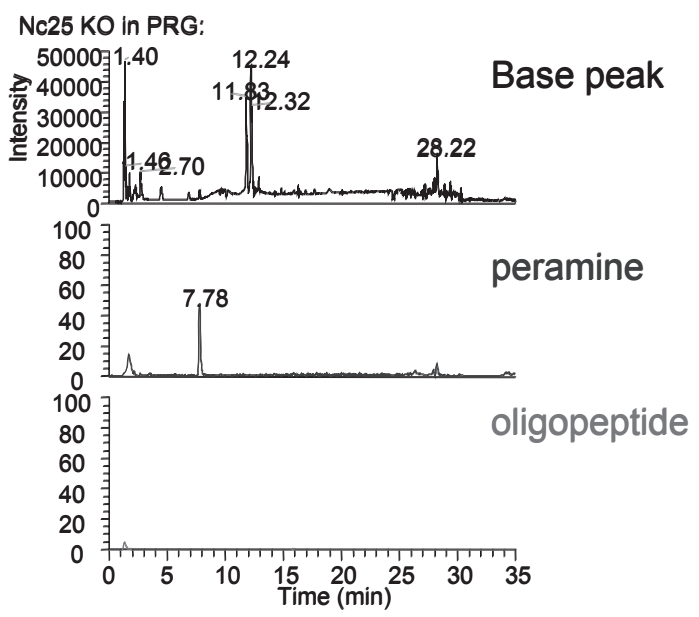

importance of discriminating between different tissue types in metabolomic studies. Significant differences were identified between endophyte-infected and uninfected ryegrass for some of the compounds analysed. These included an increase of $10-20 \%$ for some high molecular weight and low molecular weight carbohydrates in endophyte-infected grass, the presence of mannitol (a sugar alcohol) only in infected ryegrass, and a reduced level of total free amino acids in endophyte-infected ryegrass, which included large reductions in asparagine, aspartate, pipecolinic acid and gamma aminobutyric acid.

In addition to studying the symbiosis as a whole, we are also using metabolomics to try and determine the function of unknown genes. Indeed, one of the original goals of metabolomics was to determine the metabolic outcome of gene deletions (Raamsdonk et al. 2001). We are comparing the metabolite profiles of wildtype endophyte with those of endophytes containing specific gene disruptions. These have so far included uncharacterised NRPS genes (L. Johnson et al. unpublished), Nc25 (Johnson et al. 2007d), and adenylate cyclase (Voisey et al. 2007a).

\section{Integration of Approaches}

In summary, we have used a multidisciplinary approach to obtain novel information on the $N$. lolii/ryegrass symbiosis. We have identified plant and fungal differentially expressed genes, some of which may be important in this association, and have also shown that endophyte infection has a profound affect on host plant metabolism. The combination of functional analysis of gene expression and plant metabolic pathways, that appear to be directly manipulated by the ryegrass endophyte, will allow us in the future to develop metabolic models that may assist in better understanding how symbiotic and pathogenic fungi interact with plants.

The longer term benefits will be an improved ability to discover or develop superior endophyte types for pasture protection and animal production through application of the knowledge generated from the molecular interaction between the plant and endophyte. In addition, understanding how compatible symbioses are established and maintained will ultimately allow us to create new associations between endophytes and novel hosts such as cereal and rice crops. 
Figure 5 Functional categories assigned to ESTs in libraries CS32 (A) and CS36 (B) based on selected categories from the MIPS Functional Catalogue (FunCat). 42\% and 64\% of ESTs annotated with at least one category in CS32 and CS36, respectively, are displayed

Key

$\square 01$ Metabolism
$\square 01.01$ Amino acid metabolism
$\square 01.05$ C-compound and carbohydrate metabolism
$\square 01.06$ Lipid, fatty acid and isoprenoid metabolism
$\square 01.20$ Secondary metabolism
$\square 02$ Energy
$\square 02.01$ Glycolysis and gluconeogenesis
$\square 02.07$ Pentose-phosphate pathway
$\square 02.10$ Tricarboxylic-acid pathway
$\square 02.19$ Metabolism of energy reserves
$\square 02.30$ Photosynthesis
$\square 04$ Storage protein
$\square 10$ Cell cycle and DNA processing
$\square 11$ Transcription
$\square 12$ Protein synthesis
$\square 14$ Protein fate
$\square 16$ Protein with binding function or cofactor requirement
$\square 18$ Protein activity regulation
$\square 20$ Cellular transports
$\square 30$ Cellular communicationisignal transduction mechanism
$\square 32$ Cell rescue, defense and virulence
$\square 32.01$ Stress response
$\square 32.05$ Disease, virulence and defense
$\square 34$ Interaction with the cellular environment
$\square 36$ Interaction with the environment
$\square 36.20$ Plantifungal specific systemic sensing and response
$\square 38$ Tranposable elements, viral and plasmid proteins
$\square 40$ Cell fate
$\square 41$ Development
$\square 42$ Biogenesis of cellular components
$\square 43$ Cell type differentiation
$\square 45$ Tissue differentiation
$\square 47$ Organ differentiation

\section{ACKNOWLEDGEMENTS}

We would like to acknowledge all our colleagues at AgResearch who have contributed in some way to this work, including Zaneta Park and Manasa Ramakrishna for help with GeneChip ${ }^{\circledR}$ analysis, and Alan McCulloch for assembling the EST sequences and providing database support. We would also like to thank Jude Bond, Fiona Kwan, Bill Jordan (Victoria University, New Zealand) and Paul Haynes (University of Arizona, USA) for assistance with proteomic analysis. Funding has been provided by the Foundation of Research Science and Technology through contracts C10X0203 and AGRX0204. Additional funding came from AgInitiatives and FRST non-specific output funding from contract numbers 5598/1 and 9959-1.
A

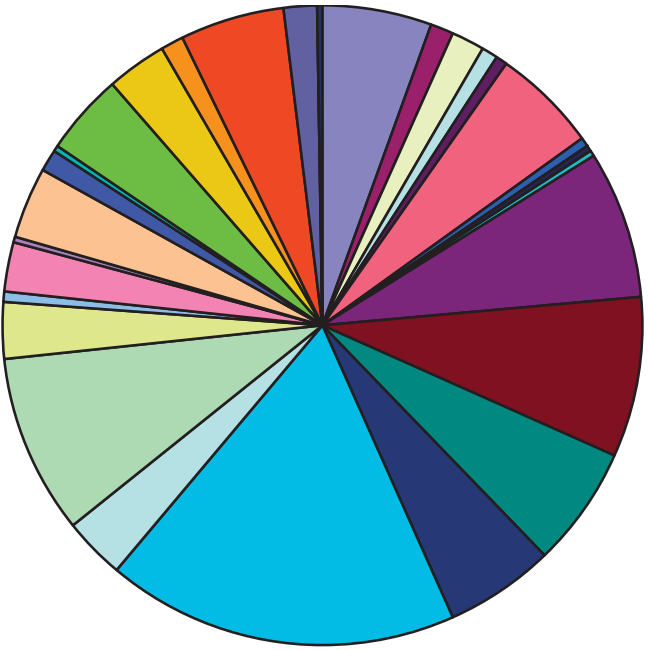

B

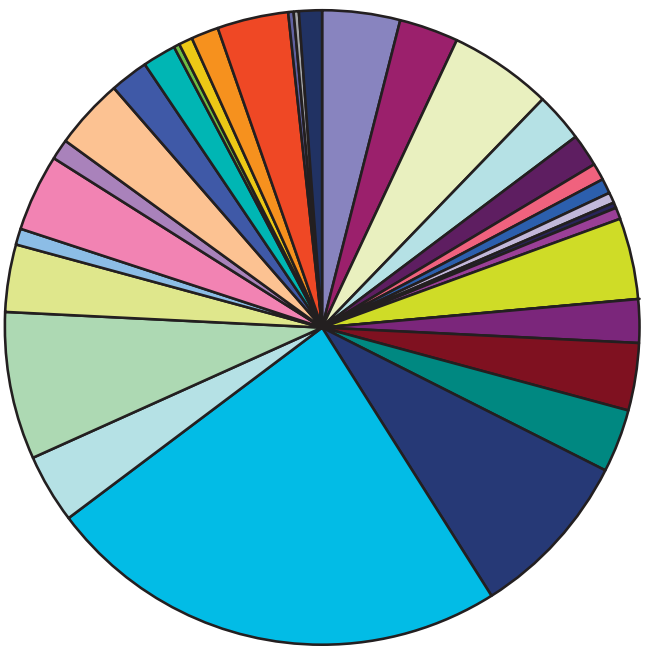

\section{REFERENCES}

Arechavaleta, M.; Bacon, C.W.; Hoveland, C.S.; Radcliffe, D.E. 1989. Effect of the tall fescue endophyte on plant response to environmental stress. Agronomy Journal 81: 83-90.

Bacon, C.W.; Porter, J.K.; Robbins, J.D.; Luttrell, E.S. 1977. Epichloë typhina from toxic tall fescue grasses. Applied Environmental Microbiology 34: 576-581.

Bendtsen, J.D.; Nielsen, H.; von Heijne, G.; Brunak, S.; 2004. Improved prediction of signal peptides: SignalP 3.0. Journal of Molecular Biology 340: 783-795.

Bhall, R.; Narasimhan, K.; Swarup, S. 2005. Metabolomics and its role in understanding cellular responses in plants. Plant Cell Reports 24: 562-571. 
Figure 6 Fungal differentially expressed genes $(F D R \leq 0.05)$ subgroups with log2-ratio cut-offs.
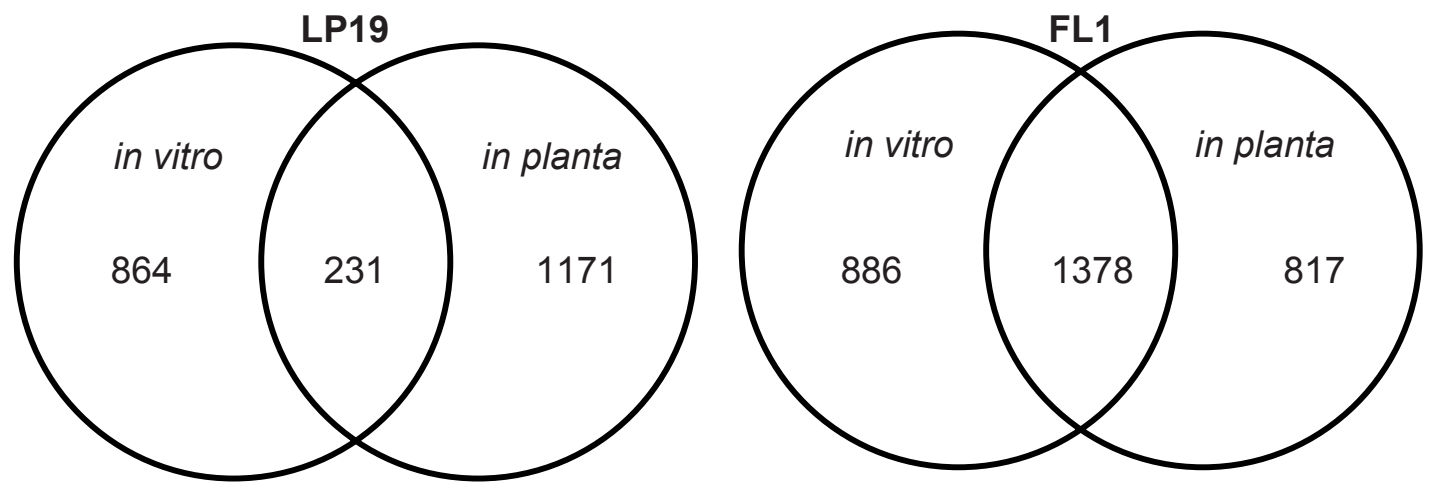

\begin{tabular}{|c|c|}
\hline Log ratio & Fungal gene subgroups \\
\hline$<-1$ & UP-regulated in-vitro \\
\hline$>1$ & UP-regulated in-planta \\
\hline$[-1,1]$ & Non-differentially expressed \\
\hline
\end{tabular}

Figure 7 2-DE analysis of total proteins from N. Iolii strain Lp19 cultures grown for 14 days in potato dextrose broth. Samples were separated in the first dimension using $24 \mathrm{~cm}$ IPG strips (pl 3-10) and in the second dimension on 12\% SDS PAGE gels. The proteins were detected with colloidal Coomassie blue stain. Spots were manually excised from the gels as indicated and subjected to in-gel digestion with trypsin prior to MALDI-TOF MS analysis.

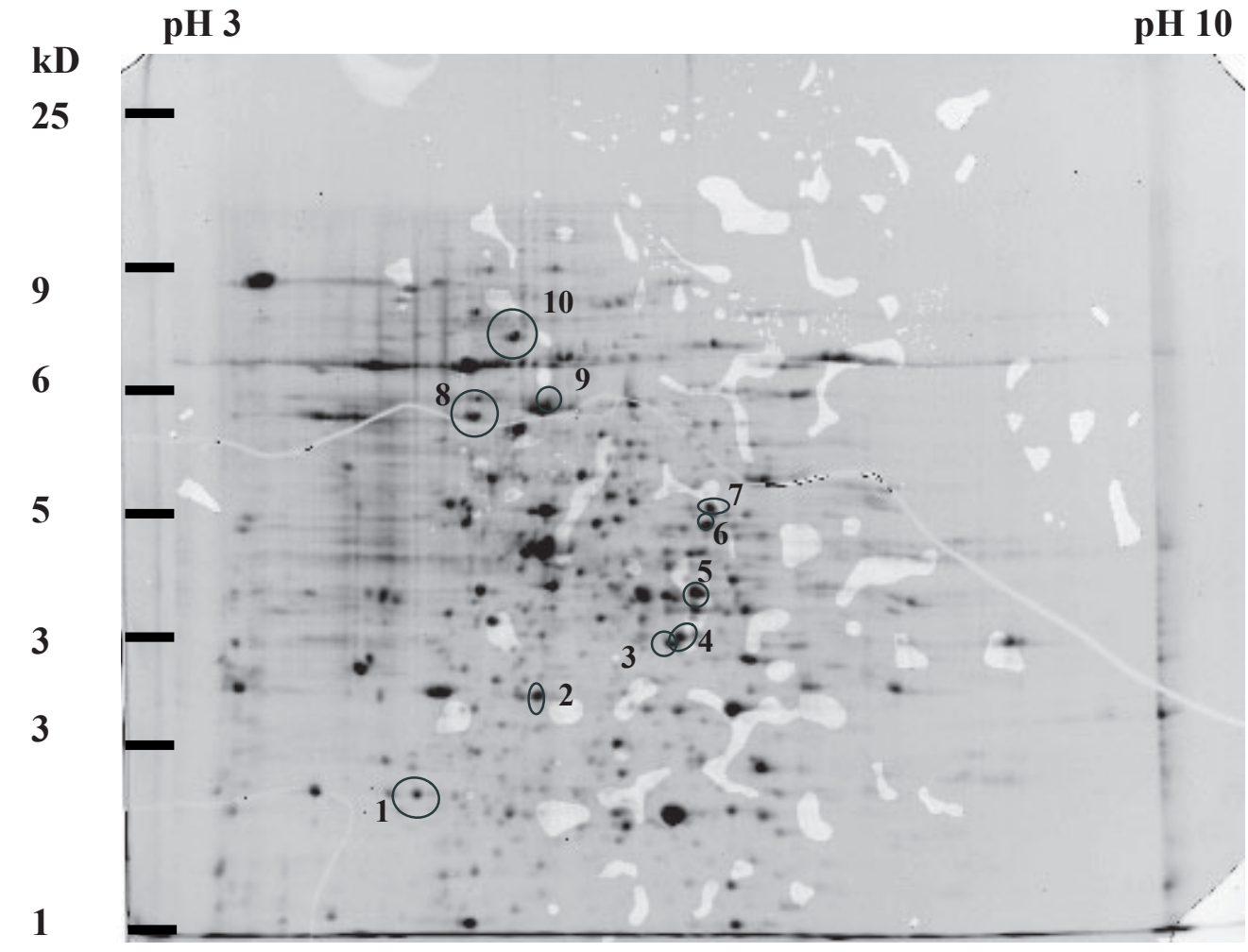


Blankenship, J.D.; Spiering, M.J.; Wilkinson, H.H.; Fannin, F.F.; Bush, L.P.; Schardl, C.L. 2001. Production of loline alkaloids by the grass endophyte, Neotyphodium uncinatum, in defined media. Phytochemistry 58: 395-401.

Bush, L.P.; Wilkinson, H.H.; Schardl, C.L. 1997. Bioprotective alkaloids of grass-fungal endophyte symbioses. Plant Physiology 114: 1-7.

Cao, M.; Johnson, L.; Johnson, R.; Koulman, A.; Lane, G.A.; Rasmussen, S. 2007. Joint analyses of transcriptomic and metabolomic data to probe ryegrass-endophyte symbiosis. pp. $195 n$ : Proceedings of the 6th International Symposium on Fungal Endophytes of Grasses. Grassland Research and Practice Series No 13. New Zealand Grassland Association.

Clay, K.; Holah, J. 1999. Fungal endophyte symbiosis and plant diversity in successional fields. Science 285: 1742-1745.

Craven, K.D.; Blankenship, J.D.; Leuchtmann, A.; Hignight, K.; Schardl, C.L. 2001. Hybrid fungal endophytes symbiotic with the grass Lolium pratense. Sydowia 53: 44-73.

Diachenko, L.; $\quad$ Lau, Y.F.; Campbell, A.P.; Chenchik, A.; Mogadam, F.; Huang, B.; Lukyanov, S.; Lukyanov, K.; Gurskaya, N.; Sverdlov, E.D.; Siebert, D. 1996. Suppression Subtractive Hybridization: A method for generating differentially regulated or tissue-specific cDNA probes and libraries. Proceedings of the National Academy of Science USA 93: 6025-6030.

Easton, H.S.; Latch, G.C.; Tapper, B.A.; Ball, O.J. 2002. Ryegrass host genetic control of concentrations of endophyte-derived alkaloids. Crop Science 42: 51-57.

Fiehn, O. 2002. Metabolomics - the link between genotypes and phenotypes. Plant Molecular Biology 48: 155-171.

Finking, R.; Marahiel, M.A. 2004. Biosynthesis of nonribosomal peptides 1. Annual Review of Microbiology 58: 453-488.

Fleetwood, D.J.; Scott, B.; Lane, A.; Tanaka, A.; Johnson, R.D. 2006. A complex ergovaline gene cluster in Epichlö̈ endophytes of grasses. Applied Environmental Microbiology: in press.

Fletcher, L.R.; Harvey, I.C. 1981. An association of a Lolium endophyte with ryegrass staggers. New Zealand Veterinary Journal 29: 185-186.

Fridman, E.; Pichersky, E. 2005. Metabolomics, genomics, proteomics, and the identification of enzymes and their substrates and products. Current Opinions in Plant Biology 8: 242-248.

Gaffoor, I.; Brown, D.W.; Plattner, R.; Proctor, R.H.; Qi, W.; Trail, F. 2005. Functional analysis of the polyketide synthase genes in the filamentous fungus Gibberella zeae (anamorph Fusarium graminearum). Eukaryot Cell 4: 1926-1933.

Gallagher, R.T.; White, E.P.; Mortimer, P.H. 1981. Ryegrass staggers: isolation of potent neurotoxins lolitrem A and lolitrem B from staggers-producing pastures. New Zealand Veterinary Journal 29: 189-190.

Glenn, A.E.; Bacon, C.W.; Price, R.; Halin, R.T. 1996. Molecular phylogeny of Acremonium and its taxonomic implications. Mycologia 88: 369-383.

Gwinn, K.D.; Gavin, A.M. 1992. Relationship between endophyte infestation level of tall fescue seed lots and Rhizoctonia zeae seedling disease. Plant Disease 76: 911-914.

Gygi, S.P.; Rochon, Y.; Franza, B.R.; Aebersold, R. 1999. Correlation between protein and mRNA abundance in yeast. Molecular Cell Biology 19: 1720-1730.

Harzer, H. ; Johnson, R.; Rasmussen, S.; Voisey, C.; Johnson, L. 2007. Characterisation of a novel endophyte NRPS gene and its role in endophyte-grass symbioses. pp. 491 In: Proceedings of the 6th International Symposium on Fungal Endophytes of Grasses. Grassland Research and Practice Series No 13. New Zealand Grassland Association.

Johnson, R.D., Voisey, C.R., Pratt, J., Johnson, L.J., Bryan, G.T., 2007a. Identification of NRPS gene families from Neotyphodium/Epichloe endophytic fungi that form mutualistic associations with cool season grasses. pp. 495 In: Proceedings of the 6th International Symposium on Fungal Endophytes of Grasses. Grassland Research and Practice Series No 13. New Zealand Grassland Association.

Johnson, L.; Steringa, M.; Koulman, A.; Christensen, M.; Johnson, R.; Voisey, C.; Bryan, G.; Lamont, I.; Rasmussen, S., 2007b. Biosynthesis of an extracellular siderophore is essential for maintenance of mutualistic endophyte-grass symbioses. pp. 177 In: Proceedings of the 6th International Symposium on Fungal Endophytes of Grasses. Grassland Research and Practice Series No 13. New Zealand Grassland Association.

Johnson, L.J., Voisey, C.R., Johnson, R.D., Khan, A.K., Park, Z.A., Ramakrishna, M., Cao, M., Simon, D., Christensen, M., Bryan, G.T., Rasmussen, S., 2007c. Dual Affymetrix GeneChip ${ }^{\circledR}$ analysis of the perennial ryegrass-endophyte symbiosis. pp. 509 In: Proceedings of the 6th International Symposium on Fungal Endophytes of Grasses. Grassland Research and Practice Series No 13. New Zealand Grassland Association.

Johnson, R.D.; Borchert, S.; Christensen, M.; Johnson, L.J.; Koulman, A.; van Gils, M.J.; Bryan, G. 2007d. A gene identified from Neotyphodium lolii is expressed only in planta and regulates the biosynthesis of a putative oligopeptide secondary metabolite. pp. 485 In: Proceedings of the 6th International Symposium on Fungal Endophytes of Grasses. Grassland Research and Practice Series No 13. New Zealand Grassland Association.

Johnson, R.D., Khan, A.K., Voisey, C.R., Bassett, S., Gaborit C., Johnson, L.J., Christensen, M., McCulloch, A., Bryan, G.T. 2007e. Analysis of expressed sequence tags derived from the endophytic fungus Neotyphodium lolii grown in vitro and in association with its host plant perennial ryegrass. pp 143 In: Proceedings of the 6th International Symposium on Fungal Endophytes of Grasses. Grassland Research and Practice Series No 13. New Zealand Grassland Association.

Johnson, L.J.; Johnson, R.D.; Schardl, C.L.; Panaccione, D.G. 2003. Identification of differentially expressed genes in the mutualistic association of tall fescue with Neotyphodium coenophialum. Physiological and Molecular Plant Pathology 63: 305-317.

Kimmons, C.A.; Gwinn, K.D.; Bernard, E.C. 1990. Nematode reproduction on endophyte-infected and endophyte-free tall fescue. Plant Disease 74: 757-761.

Lane, G.A.; Christensen, M.J.; Miles, C.O. 2000. Coevolution of fungal endophytes with grasses: the significance of secondary metabolites. pp. 342-388. In: Microbial Endophytes. Eds. Bacon, C.W.; White, J.F. Jr. Marcel Dekker, New York.

Lane, G.A., Cao, M., Johnson, L.J., Koulman, A., Popay, A.J., Rasmussen, S., Tapper, B.A. 2007. Anti-herbivore factors of grass endophytes: new prospects from metabolomics. pp. 307 In: Proceedings of the 6th International Symposium on Fungal Endophytes of Grasses. Grassland Research and Practice Series No 13. New Zealand Grassland Association.

Li, H.M.; Sullivan, R.; Moy, M.; Kobayashi, D.Y.; Belanger. F.C. 2004 Expression of a novel chitinase by the fungal endophyte in Poa ampla. Mycologia 96: 526-536. 
Malinowski, D.P.; Belesky, D.P. 1999. Neotyphodium coenophialum-endophyte infection affects the ability of tall fescue to use sparingly available phosphorus. Journal of Plant Nutrition 22: 835-853.

Malinowski, D.P.; Brauer, D.K.; Belesky, D.P. 1999. Neotyphodium coenophialum-endophyte affects root morphology of tall fescue grown under phosphorus deficiency. Journal of Agronomy Crop Science 183: 91-102.

Moy, M.; Li, H.M.; Sullivan, R.; White, J.F. Jr.; Belanger, F.C. 2002. Endophytic fungal beta-1,6-glucanase expression in the infected host grass. Plant Physiology 130: 1298-1308.

Panaccione, D.G.; Johnson, R.D.; Wang, J.; Young, C.A.; Damrongkool, P.; Scott, B.; Schardl, C.L. 2001. Elimination of ergovaline from a grass-Neotyphodium endophyte symbiosis by genetic modification of the endophyte. Proceedings of the National Academy of Science U S A. 98: 12820-12825.

Perkins, D.N.; Pappin, D.J.; Creasy, D.M.; Cottrell, J.S. 1999. Probability-based protein identification by searching sequence databases using mass spectrometry data. Electrophoresis 20: 3551-3567.

Philipson, M.N.; Christey, M.C. 1986. The relationship of host and endophyte during flowering, seed formation, and germination of Lolium perenne. New Zealand Journal of Botany 24: 125-134.

Raamsdonk, L.M.; Teusink, B.; Broadhurst, D.; Zhang, N.S.; Hayes, A.; Walsh, M.C.; Berden, J.A.; Brindle, K.M.; Kell, D.B.; Rowland, J.J.; Westerhoff, H.V.; van Dam, K.; Oliver, S.G. 2001. A functional genomics strategy that uses metabolome data to reveal the phenotype of silent mutations. Nature Biotechnology 19: 45-50.

Reddy, P.V.; Lam, C.K.; Belanger, F.C. 1996. Mutualistic fungal endophytes express a proteinase that is homologous to proteases suspected to be important in fungal pathogenicity. Plant Physiology 111: 1209-1218.

Ruepp, A.; Zollner, A.; Maier, D.; Albermann, K.; Hani, J.; Mokrejs, M.; Tetko, I. Guldener, U.; Mannhaupt, G.; Munsterkotter, M.; Mewes, H.W. 2004. The FunCat, a functional annotation scheme for systematic classification of proteins from whole genomes. Nucleic Acids Research 32: 5539-5545.

Schardl, C.L. 2001 Epichloë festucae and related mutualistic symbionts of grasses. Fungal Genetics and Biology 33: 69-82.

Schardl, C.L.; Phillips, T.D. 1997. Protective grass endophytes: where are they from and where are they going? Plant Disease 81: 430-438.

Schardl, C.L.; Leuchtmann, A.; Spiering, M.J. 2004. Symbioses of grasses with seedborne fungal endophytes. Annual Review of Plant Biology 55: 315-340.

Scott, B. 2001. Epichloë endophytes: fungal symbionts of grasses. Current Opinion in Microbiology 4: 393-398.

Spiering, M.J.; Moon, C.D.; Wilkinson, H.H.; Schardl, C.L. 2005. Gene clusters for insecticidal loline alkaloids in the grass-endophytic fungus Neotyphodium uncinatum. Genetics 169: 1403-1414.

Spiering, M.J.; Wilkinson, H.H.; Blankenship, J.D.; Schardl, C.L. 2002. Expressed sequence tags and genes associated with loline alkaloid expression by the fungal endophyte Neotyphodium uncinatum. Fungal Genetics and Biology 36: 242-254.

Sumner, L.W.; Mendes, P.; Dixon, R.A. 2003. Plant metabolomics: large-scale phytochemistry in the functional genomics era. Phytochemistry 62: 817-836.

Tan, Y.Y.; Spiering, M.J.; Scott, V.; Lane, G.A.; Christensen, M.J.; Schmid, J. 2001. In planta regulation of extension of an endophytic fungus and maintenance of high metabolic rates in its mycelium in the absence of apical extension. Applied Environmental Microbiology 67: 5377-5383.

Tanaka, A.; Tapper, B.A.; Popay, A.; Parker, E.J.; Scott, B. 2005. A symbiosis expressed non-ribosomal peptide synthetase from a mutualistic fungal endophyte of perennial ryegrass confers protection to the symbiotum from insect herbivory. Molecular Microbiology 57: 1036-1050.

Tanaka, A.; Christensen, M.J.; Takemoto, D.; Park, P.; Scott, B. 2006. Reactive oxygen species play a role in regulating a fungus-perennial ryegrass mutualistic interaction. Plant Cell 18: 1052-1066.

Voisey, C.R.; Khan, A.K.; Park-Ng, Z.A.; Johnson, L.J.; Johnson, R.D.; Cao, M.; Bassett, S.; Gaborit, C.N.; McCulloch, A.F.; Simon, D.; Ramakrishna, M.; Rasmussen, S.; Bryan, G.T. 2007. Development of an Affymetrix dual genome (Neotyphodium lolii/ Lolium perenne) Symbiosis GeneChip ${ }^{\circledR}$. pp. 505 In: Proceedings of the 6th International Symposium on Fungal Endophytes of Grasses. EGrassland Research and Practice Series No. 13. New Zealand Grassland Association.

Wang, J., Machado, C., Panaccione, D.G., Tsai, H.F., Schardl, C.L., 2004. The determinant step in ergot alkaloid biosynthesis by an endophyte of perennial ryegrass. Fungal Genetics and Biology 41: 189-98.

Young, C.A.; Bryant, M.K.; Christensen, M.J.; Tapper, B.A.; Bryan, G.T.; Scott, B. 2005. Molecular cloning and genetic analysis of a symbiosis-expressed gene cluster for lolitrem biosynthesis from a mutualistic endophyte of perennial ryegrass. Molecular Genetics and Genomics 274: 13-29.

Young, C.A.; Felitti, S.; Shields, K.; Spangenberg, G.; Johnson, R.D.; Bryan, G.T.; Saikia, S.; Scott, B. 2006. A complex gene cluster for indole-diterpene biosynthesis in the grass endophyte Neotyphodium lolii. Fungal Genetics and Biology 43: 679-693. 